\title{
IMPLEMENTASI WAKAF TUNAI DALAM PENGEMBANGAN PEREKONOMIAN DAN INFRASTRUKTUR
}

\section{IMPLEMENTATION OF CASH WAKAF IN ECONOMIC AND INFRASTRUCTURE DEVELOPMENT}

\author{
D. Rahmasari1a, F. Fara², L. Rahmawati ${ }^{3}$, N. El-Nadia4 ${ }^{4}$, N. Hadi ${ }^{5}$ \\ 1aProgam Studi Ekonomi Syariah Fakultas Ekonomi dan Bisnis Islam Universitas Islam \\ Negeri Sunan Ampel Surabaya, Jl. Ahmad Yani No. 117 Surabaya 60237, e-mail: \\ raahmaasaari@gmail.com \\ 2Progam Studi Ekonomi Syariah Fakultas Ekonomi dan Bisnis Islam Universitas Islam \\ Negeri Sunan Ampel Surabaya, Jl. Ahmad Yani No. 117 Surabaya 60237, e-mail: \\ firafara.f23@gmail.com \\ 3Progam Studi Ekonomi Syariah Fakultas Ekonomi dan Bisnis Islam Universitas Islam \\ Negeri Sunan Ampel Surabaya, Jl. Ahmad Yani No. 117 Surabaya 60237, e-mail: \\ lilikrahmawati@uinsby.ac.id \\ 4Progam Studi Ekonomi Syariah Fakultas Ekonomi dan Bisnis Islam Universitas Islam \\ Negeri Sunan Ampel Surabaya, Jl. Ahmad Yani No. 117 Surabaya 60237, e-mail: \\ nadandadz@gmail.com \\ 5Progam Studi Ekonomi Syariah Fakultas Ekonomi dan Bisnis Islam Universitas Islam \\ Negeri Sunan Ampel Surabaya, Jl. Ahmad Yani No. 117 Surabaya 60237, e-mail: \\ nurrohmanhadi5@gmail.com
}

\begin{abstract}
ABSTRAK
Penelitian ini bertujuan untuk mengetahui implementasi wakaf tunai dalam pengembangan perekonomian dan infrastruktur. Metode penelitian menggunakan jenis penelitian kualitatif dengan pendekatan studi kepustakaan dan teknik analisis data menggunakan analisis isi. Hasil penelitian menunjukkan bahwa wakaf tunai dapat menjadi solusi dan berkontribusi dalam mengurai masalah perekonomian di suatu negara. Hal ini dapat dilihat dalam pemanfaatan aset wakaf yang bersifat publik seperti bidang properti, reklamasi tanah dan pertanian serta aset wakaf produktif lainnya. Selain itu, wakaf tunai juga dapat menjadi solusi alternatif dalam pembiayaan infrastruktur di Indonesia. Dengan menggunakan wakaf tunai pembangunan tidak perlu memikirkan bagi hasil karena wakaf bukan termasuk pinjaman.
\end{abstract}

Kata Kunci: Wakaf Tunai, Ekonomi, Infrastruktur

\begin{abstract}
This study aims to determine the implementation of cash waqf in the economy and infrastructure development. The research method used was qualitative research with a literature study approach and data analysis techniques used content analysis. The results show that cash waqf can be a solution and contribute to solving economic problems in a country. This can be seen in the use of public waqf assets such as property, land reclamation and agriculture and other productive waqf assets. In addition, cash waqf can also be an alternative solution for infrastructure financing in
\end{abstract}


Indonesia. By using cash waqf development, there is no need to think about profit sharing because waqf is not a loan.

Keywords: Cash Waqf, Economy, Infrastructure

Rahmasari, D. 2020. Implementasi Wakaf Tunai dalam Pengembangan Perekonomian dan Infrastruktur. Jurnal Syarikah 6 (2): 137-150.

\section{PENDAHULUAN}

Indonesia merupakan negara berkembang dimana masih banyak kemiskinan di negara ini. Kemiskinan merupakan tolak ukur meningkat atau menurunnya pertumbuhan ekonomi dalam suatu negara. Bagi bangsa Indonesia, peran infrastruktur sangat penting kaitannya terhadap kesejahteraan baik dalam hal berkurangnya kesenjangan antar wilayah, maupun berkualitasnya pertumbuhan ekonomi. Mengingat Indonesia merupakan negara kepulauan terbesar di dunia dengan persebaran penduduk yang tidak merata. Peran infrastruktur terutama jalan sangatlah penting dalam hal ini.

Ditinjau dari segi permasalahan pembiayaan pembangunan infrastuktur di Indonesia, wakaf tunai merupakan solusi yang memiliki potensi sangat baik. Mengingat Indonesia merupakan negara dengan populasi muslim terbesar di dunia. Sehingga banyaknya populasi serta tingginya pendapatan masyarakat muslim menjadikan wakaf tunai memiliki potensi yang cukup besar bagi bangsa Indonesia. Alternatif wakaf tunai merupakan sumber asset yang memberikan manfaat sepanjang masa, karena wakaf tunai tidak bersifat pinjaman. Sehingga dalam pembangunan infrastruktur tidak perlu memikirkan imbal hasil.

Dalam penghimpunan dana wakaf, masyarakat dapat menyetorkan dana wakaf pada Badan Wakaf Indonesia yang berperan sebagai lembaga independen untuk mengembangkan perwakafan di Indonesia yang dibantu oleh kementerian agama dalam hal penghimpunan wakaf. Dalam periode satu tahun, dana wakaf yang terhimpun dilaporkan dan disetorkan pada kementerian keuangan untuk dimasukkan dalam kas negara yang kemudian dianggarkan untuk pembangunan infrastruktur.

Penggunaan wakaf tunai dalam pembangunan infrastruktur harus digunakan untuk aktivitas sosial atau kemaslahatan umat, karena wakaf tunai merupakan pemberian yang bersifat sosial. Dalam hal ini diharapkan dapat membantu mengembangkan infrastuktur Indonesia seperti pembangunan jalan yang menjadi salah satu faktor penentu dalam penurunan tingkat ketimpangan. Ini merupakan salah satu keistimewaan wakaf tunai selain tidak perlu memikirkan imbal hasil.

\section{MATERI DAN METODE}

\section{Konsep Wakaf Tunai}

Wakaf dapat didefinisikan kedalam dua cara, yaitu secara bahasa dan secara istilah. Secara bahasa wakaf berasal dari bahasa arab waqafa yang berarti berhenti, manahan, diam ditempat, tetap berdiri. Waqafa berasal dari kata wakafayaqifu-waqfan yang sama artinya dengan habasah-yahbisu-tahbisan yang berarti manahan. Dengan kata lain, wakaf dalam bahasa arab merupakan memberikan tanah kepada orang-orang yang 
kekurangan dalam hal ekonomi (miskin) untuk ditahan, karena barang tersebut dipegang dan ditahan oleh orang lain seperti menahan tanah, hewan ternak, dan lain sebagainya. (Fauzia dan Hermawan 1988)

Secara istilah, wakaf adalah pemberian yang dilakukan dengan cara menahan (pemilikan) yang menjadikan manfaatnya tersebut dapat dimiliki oleh masyarakat umum. Disini yang dimaksud dengan kepemilikan adalah penahanan dari barang yang diwakafkan agar tidak di gadaikan, dijual, diwariskan, dihibahkan, didagangkan, maupun disewakan. Cara pemanfaatannya yaitu dengan menggunakan pemberian tersebut sesuai dengan yang dikehendaki oleh sang pemberi wakaf tetapi pemberi wakaf tersebut tanpa meminta imbalan. (Ali 1988)

Beberapa definisi lain yang berasal dari tokoh-tokoh, peraturan undangundang, dari para fuqaha, maupun Komisi Fatwa Majelis Ulama Indonesia. Definisi yang berasal dari tokoh pertama dikemukakan oleh Mundzir Qahaf yang menyebutkan wakaf sebagai pemberian harta benda yang bersifat produktif yang terlepas dari campur tangan pribadi, dan hasil dari manfaatnya disalurkan secara khusus yang dilakukan sesuai dengan tujuan wakaf. Baik dilakukan untuk kepentingan umum, masyarakat, agama, mapun pribadi (Qahaf 1995). Kemudian definisi kedua dari tokoh berasal dari AlMinawi yang mendefinisikan wakaf dengan "Menahan harta benda yang dimiliki dan menyalurkan manfaatnya dengan tetap menjaga pokok barang dan keabadiannya yang berasal dari para dermawan atau pihak umum selain dari harta maksiat semata-mata karena ingin mendekatkan diri kepada Allah SWT". (AlMinawi 1990)

Definisi yang lain berasal dari peraturan perundang-undangan yang ada di Indonesia: Pertama, peraturan pemerintah nomor 28 tahun 1997 menyebutkan wakaf adalah perbuatan hukum seseorang atau badan hukum yang memisahkan sebagian dari harta kekayaannya yang berupa tanah milik dan kelembagaannya untuk selamalamanya untuk kepentingan atau keperluan umat lainnya sesuai dengan ajaran Islam. Kedua, KHI (Kompilasi Hukum Islam) yang mendefinisikan wakaf sebagai perbuatan hukum seseorang atau kelompok orang atau badan hukum yang memisahkan sebagian dari benda miliknya dan kelembagaannya untuk selama-lamanya guna kepentingan ibadah atau keperluan umum lainnya sesuai dengan ajaran Islam. Ketiga, Undang-undang Wakaf Nomor 41 tahun 2004 yang menyatakan wakaf sebagai perbuatan hukum wakif untuk memisahkan dan/atau menyerahkan sebagian harta benda miliknya untuk dimanfaatkan selamanya atau untuk jangka waktu tertentu sesuai dengan kepentingannya guna keperluan ibadah dan/atau kesejahteraan umum menurut syari'ah. Keempat, Peraturan Wakaf Indonesia Nomor 4 tahun 2010 tentang pedoman pengelolaan dan pengembangan harta benda, wakaf didefinisikan sebagai perbuatan hukum wakif untuk memisahkan dan/atau menyerahkan sebagian harta benda miliknya untuk dimanfaatkan selamanya atau untuk jangka waktu tertentu sesuai dengan kepentingannya guna keperluan ibadah dan/atau kesejahteraan umum menurut syariah. (Hazami 2016)

Definisi atau pengertian terakhir berasal dari para fuqaha yang memiliki pendapat masing-masing, diantaranya:

1. Menurut Abu Yusuf dan Muhammad bin al-Hasan, golongan Syafi'iyah dan golongan Hanafiyah yang mendefinisikan wakaf "wakaf adalah menahan harta yang memungkinkan diambil manfaatnya, tetapi bukan untuk dirinya, dibelanjakan waqif untuk mendekatkan diri kepada Allah SWT". 
2. Menurut Hanafiyah yang disadur oleh Wahbah al-Zuhaili "Wakaf adalah penghentian harta tidak bergerak dari pemilikan waqif secara hukum dan penyedekahan dan manfaatnya untuk kepentingan umum".

3. Menurut golongan Malikiyah, wakaf mempunyai arti bahwa pemilik harta memberikan manfaat harta yang dimiliki bagi mustahiq. Menurut golongan malikiyah ini harta yang digunakan berupa harta yang dapat disewakan kemudian dari sewa tersebut hasilnya diwakafkan. Sehingga orang yang ingin berwakaf tidak harus menunggu yang bersangkutan untuk memiliki benda yang diwakafkan hanya dengan cara cukup menyewa benda. Namun kelemahan dari pendapat ini akan menyebabkan lemahnya lembaga wakaf dan tidak sesuai dengan pendapat jumhur ulama yang lain yang menyatakan bahwa benda yang diwakafkan itu haruslah benda yang tetap zatnya dan juga dapat dimanfaatkan secara terus menerus (Hazami 2016).

Menurut Komisi Fatwa Majelis Ulama Indonesia yang mendefinisikan wakaf adalah perbuatan hukum seseorang atau kelompok atau badan hukum yang memisahkan sebagian benda dari benda miliknya guna kepentingan ibadah atau keperluan umum lainnya sesuai dengan ajaran Islam dan benda wakaf merupakan segala benda bergerak ataupun tidak bergerak yang memiliki daya tahan yang tidak hanya sekali pakai dan bernilai menurut ajaran Islam. (KHI)

\section{Dasar Hukum Wakaf Tunai}

Secara umum tidak terdapat ayat AlQur'an yang menjelaskan konsep wakaf secara jelas, karena wakaf termasuk golongan infaq, maka dasar yang digunakan oleh para ulama dalam menjelaskan konsep wakaf berdasarkan pada ayat-ayat Al-Qur'an yang berkenaan dengan infaq. Diantaranya terdapat pada surat Al-Baqarah ayat 267:

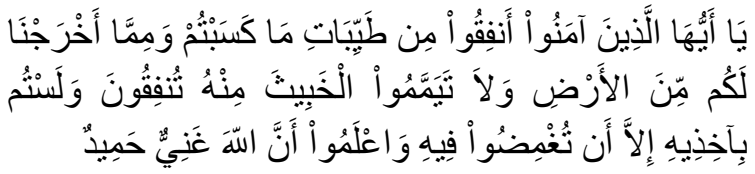

Artinya: "Hai orang-orang yang beriman, nafkahkanlah (di jalan Allah) sebagian dari hasil usahamu yang baik-baik dan sebagian dari apa yang kami keluarkan dari bumi untuk kamu. dan janganlah kamu memilih yang buruk-buruk lalu kamu menafkahkan daripadanya, padahal kamu sendiri tidak mau mengambilnya melainkan dengan memicingkan mata terhadapnya. dan Ketahuilah, bahwa Allah Maha Kaya lagi Maha Terpuji".

Kemudian terdapat pada surat AlBaqarah ayat 261:

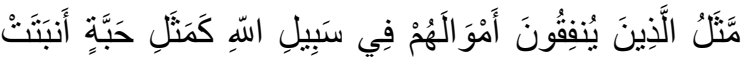

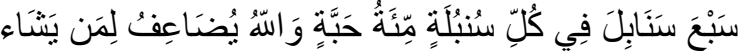

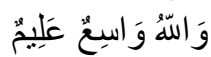

Artinya: "Perumpamaan (nafkah yang dikeluarkan oleh) orang-orang yang menafkahkan hartanya di jalan Allah adalah serupa dengan sebutir benih yang menumbuhkan tujuh bulir, pada tiap-tiap bulir seratus biji. Allah melipat gandakan (ganjaran) bagi siapa yang dia kehendaki. dan Allah Maha luas (karunia-Nya) lagi Maha Mengetahui".

Serta pada Surat Ali Imran ayat 92:

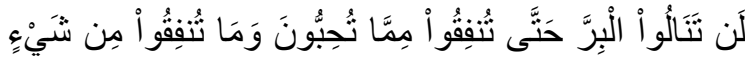

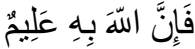

Artinya: "Kamu sekali-kali tidak sampai kepada kebajikan (yang sempurna), sebelum kamu menafkahkan sehahagian harta yang kamu cintai, dan apa saja yang kamu nafkahkan Maka Sesungguhnya Allah mengetahuinya".

Ada pula hadits yang menjadi dasar hukum wakaf yaitu hadits yang diriwayatkan oleh Abdullah bin Umar, 
bahwa Umar bin Khatab mendapat sebidang tanah di Khaibar. Kemudian Umar bin Khatab menghadap Rasulullah SAW untuk memohon petunjuk tentang apa yang sepatutnya dilakukan terhadap tanah tersebut. Umar berkata kepada Rasulullah SAW, "Ya Rasulullah, saya mendapatkan sebidang tanah di Khaibar itu. Karena itu saya memohon petunjuk tentang apa yang sepatutnya saya lakukan pada tanah itu". Rasulullah SAW menjawab, "Jika engkau mau, tahanlah tanahmu itu dan sedekahkan". Lalu Umar mensedekahkannya dan mensyaratkan bahwa tanah itu tidak boleh diwariskan. Umar juga menyalurkan hasil tanah itu untuk orang-orang fakir, ahli familinya, membebaskan budak, orang-orang yang berjuang di jalan Allah, orang-orang yang kehabisan bekal dalam perjalanan dan tamu. Penguasa wakaf tunai sendiri boleh memakan hasil wakaf tersebut dalam batas-batas yang ma'ruf (biasa).

Selain dari Al-Qur'an dan Hadits, para ulama telah menyepakati (Ijma') menerima wakaf sebagai satu amal jariyah yang disyariatkan dalam agama Islam. Tidak ada satu orang pun yang menolak praktik wakaf dalam Islam, karena wakaf telah menjadi amalan yang senantiasa dijalankan dan diamalkan sejak zaman Rasulullah SAW hingga saat ini.

Di dalam konteks kenegaraan, pemerintah Indonesia telah menetapkan undang-undang khusus untuk mengatur tentang wakaf di Indonesia, yaitu Undang-Undang Nomor 41 Tahun 2004 tentang Wakaf, untuk melengkapi undang-undang tersebut, pemerintah juga menetapkan Peraturan Pemerintah No. 42 Tahun 2006 tentang Pelaksanaan Undang-Undang No. 41 Tahun 2004.

\section{Sejarah Wakaf Tunai}

Menurut Syafrudin (2010) Perilaku sejenis wakaf telah dikenal manusia sebelum Islam datang. Terlepas dari agama dan kepercayaan yang mereka anut sesungguhnya, manusia telah mengenal beberapa bentuk praktik pendayagunaan harta benda, yang substansinya tidak jauh berbeda dengan wakaf dalam Islam. Hal ini dikarenakan pada dasarnya, umat manusia sudah menyembah Tuhan melalui ritual keagamaan sesuai kepercayaan mereka. Hal inilah yang kemudian menjadi faktor pendorong bagi setiap umat beragama untuk mendirikan bangunan peribadatannya masing-masing. Mereka yang memiliki kepedulian serta perhatian terhadap kelangsungan agamanya rela melepaskan sebagian tanahnya atau menyumbangkan sebagian harta miliknya untuk kepentingan rumah peribadatan. Contoh yang paling nyata dari adanya praktik wakaf sebelum Islam adalah dibangunnya al-Ka'bah al-Musyarrafah oleh Nabi Ibrahim as. Hanya saja, dalam perjalanan waktu, Ka'bah pernah digunakan sebagai tempat penyembahan berhala, padahal sebelumnya adalah tempat beribadah kepada Allah SWT.

Jika praktik wakaf telah dikenal sebelum Islam, maka yang membedakannya dengan wakaf dalam Islam adalah bahwa praktik wakaf yang diamalkan masyarakat jahiliyah dilakukan semata-mata hanya untuk mencari prestise (kebanggaan). Sedangkan dalam Islam bertujuan untuk mencari ridha Allah dan sebagai sarana mendekatkan diri kepada-Nya. Dalam sejarah Islam, wakaf dikenal sejak masa Rasulullah Shollallahu Alaihi Wasalam karena wakaf disyariatkan pada tahun kedua Hijriyah.

Ada dua pendapat yang berkembang di kalangan fuqaha' tentang siapa yang pertama kali melaksanakan syariat wakaf. Menurut sebagian pendapat ulama mengatakan bahwa yang pertama kali melaksanakan wakaf adalah Rasulullah SAW yaitu wakaf tanah milik Rasulullah untuk dibangun masjid. Sebagian ulama menyatakan bahwa yang pertama kali melaksanakan syariat wakaf adalah Umar bin Khatab. Pendapat ini berdasarkan 
hadits yang diriwayatkan Ibnu Umar ra, sebagaimana telah dikemukakan di atas. Praktek wakaf juga berkembang luas pada masa dinasti Umayah dan dinasti Abbasiyah dan dinasti sesudahnya, banyak orang berbondong-bondong untuk melaksanakan wakaf, dan wakaf tidak hanya untuk orang fakir dan miskin saja, tetapi wakaf menjadi modal untuk membangun lembaga pendidikan, membangun perpustakaan dan membayar gaji para stafnya, gaji para guru dan beasiswa untuk para siswa dan mahasiswa. Antusiasme masyarakat kepada pelaksanaan wakaf telah menarik perhatian negara untuk mengatur pengelolaan wakaf sebagai sektor untuk membangun solidaritas sosial dan ekonomi masyarakat.

Praktik wakaf tunai (cash waqf) pertama kali dipakai pada masa Utsmani di Mesir, di akhir abad ke-16 (1555-1823 M). Pada era Utsmani di Mesir, berkembang pemakaian fikih Hanafi dalam menjalankan aktivitas bisnis dan sosialnya. Imam Muhammad asy-Syaibani menjelaskan bahwa sekalipun tidak ada dukungan hadis yang kuat, penggunaan harta bergerak sebagai wakaf dibolehkan, jika memang hal itu sudah menjadi kebiasaan umum pada daerah tertentu. Bahkan bagi Imam Muhammad alSarakhsi, kebiasaan umum tidak selalu menjadi persyaratan dalam penggunaan harta bergerak sebagai harta wakaf. Bahkan menurut Crecelius, Dia menyatakan: "No Islamic State was more energetic in its production of statistical records, more systematic in its record keeping, and more assiduous in preserving these records than the Ottoman Empire." Artinya: "Tidak ada negara Islam yang lebih energik dalam menghasilkan wakaf dan catatan statistiknya, lebih sistematis dalam menjaga catatan tersebut, serta lebih ketat dalam mengawasi catatan tersebut ketimbang Dinasti Ustmani."

Terdapat tiga alasan mendasar kenapa ahli fiqh era Utsmani menyusun bangunan wakaf tunai: pertama, pandangan bahwa aset bergerak dapat menjadi harta wakaf. Kedua, penilaian dan penerimaan atas uang sebagai aset bergerak. Ketiga, persetujuan atas pemberian uang tunai."(Syafrudin: 2010).

Dalam Syafrudin (2010) Pada prinsipnya, dalam rangka mencapai tujuan dan fungsi wakaf, harta benda wakaf hanya dapat diperuntukan bagi: sarana dan kegiatan ibadah; sarana dan kegiatan pendidikan serta kesehatan; bantuan kepada fakir miskin, anak terlantar, yatim piatu, beasiswa; kemajuan dan peningkatan ekonomi umat; dan/atau kemajuan kesejahteraan umum lainnya yang tidak bertentangan dengan syariah dan peraturan perundang-undangan.

\section{Metodologi Penelitian}

Metode yang digunakan dalam penelitian ini adalah metode penelitian kualitatif. Metode kualitatif merupakan penelitian yang bersifat deskriptif dan cenderung menggunakan analisis. Proses dan makna lebih ditonjolkan pada penelitian kualitatif. Landasan teori dimanfaatkan sebagai pemandu agar fokus penelitian sesuai dengan fakta yang ada di lapangan. Tujuan dari metode ini adalah pemahaman secara luas dan mendalam terhadap suatu permasalahan yang sedang dikaji atau akan dikaji. Dalam penelitian ini akan menjabarkan mengenai implementasi dan peranan wakaf tunai terhadap pengembangan ekonomi dan infrastruktur, sehingga akan diketahui implementasi dan peranan penting dari wakaf tunai. Pada penelitian ini jenis penelitian menggunakan pendekatan studi kepustakaan (library research).

Metode penelitian kepustakaan ini digunakan untuk menyusun konsep mengenai implementasi wakaf tunai dalam pengembangan perekonomian dan infrastruktur yang nantinya dapat digunakan sebagai pijakan dalam mengembangkan langkah-langkah praktis 
sebagai acuan dalam menilai perkembangan wakaf tunai di Indonesia. Adapun langkah-langkah dalam penelitian kepustakaan menurut Kuhlthau (2002) adalah sebagai berikut :

1. Pemilihan topik.

2. Eksplorasi informasi.

3. Menentukan fokus penelitian.

4. Pengumpulan sumber data.

5. Persiapan penyajian data.

6. Penyusunan laporan.

Sumber data yang menjadi bahan penelitian ini berupa buku, jurnal dan situs internet yang terkait dengan topik yang telah dipilih. Sumber data penelitian ini terdiri dari 5 buku dan 10 jurnal, serta 3 situs internet memgenai wakaf, khususnya wakaf tunai.

Teknik pengumpulan data dalam penelitian ini adalah dokumentasi, yaitu mencari data mengenai hal-hal atau variabel yang berupa catatan, buku, makalah atau artikel, jurnal dan sebagainya (Arikunto, 2010). Instrumen penelitian dalam penelitian ini adalah daftar check-list klasifikasi bahan penelitian, skema atau peta penulisan dan format catatan penelitian.

Teknik analisis data yang digunakan adalah metode analisis isi (content analysis). Analisis ini digunakan untuk mendapatkan inferensi yang valid dan dapat diteliti ulang berdasarkan konteksnya (Kripendoff, 1993). Dalam analisis ini akan dilakukan proses memilih, membandingkan, menggabungkan dan memilah berbagai pengertian hingga ditemukan yang relevan (Serbaguna, 2005). Untuk menjaga kekelan proses pengkajian dan mencegah serta mengatasi mis-informasi (kesalahan pengertian manusiawi yang bisa terjadi karena kekurangan penulis pustaka) maka dilakukan pengecekan antar pustaka dan memperhatikan komentar pembimbing (Sutanto, 2005).

\section{HASIL DAN PEMBAHASAN}

\section{Implementasi Wakaf Tunai di Indonesia Untuk Mengembangkan Perekonomian dan Infrastruktur}

Wakaf tunai di Indonesia sudah dijalankan termasuk Badan Wakaf Indonesia dengan bekerjasama dengan Lembaga Keuangan Syariah Penerima Wakaf Uang (LKS-PWU) yang telah ditunjuk. Wakif yang berwakaf uang diberikan sertifikat wakaf tunai dapat jika wakif telah mewakafkan uangnya paling sedikit sebesar Rp 1.000.000 (satu juta rupiah) yang akan diberikan dengan syarat wakif menyertakan asal-usul dan identitas lengkap waqifnya. Hal tersebut sesuai dengan Peraturan Badan Wakaf Indonesia No. 01 tahun 2009 tentang pedoman pengelolaan dan pengembangan harta benda wakaf bergerak berupa uang.

Penghimpunan dan pengembangan wakaf uang di Indonesia bisa berjalan dengan baik karena Indonesia merupakan salah satu negara dengan penduduk umat muslim terbesar didunia, sehingga hal tersebut menjadi aset terbesar dalam proses penghumpunan dan pengembangan. Sebagaimana asumsi Cholil Nafis, apabila setiap bulan 20 juta umat Islam mengumpulkan uang wakaf senilai Rp 100.000 maka uang wakaf yang terkumpul senilai Rp 24 Triliun setiap tahunnya. Sedangkan jika terdapat 50 juta umat Islam dengan mewakafkan uangnya sebesar Rp 100.000, maka uang wakaf yang terkumpul sebanyak Rp 60 Triliun. Dan jika hanya terdapat 1 juta orang yang mewakafkan uangnya maka akan terkumpul dana sebanyak Rp 100 miliar setiap bulannya (Rp 1,2 triliun pertahun). (Nafis 2009)

Selain asumsi yang dikemukakan oleh Cholil Nafis, asumsi lain juga dikemukakan oleh Mustafa Edwin Nasution. Dimana ia juga memperkirakan jumlah umat muslim yang ada di Indonesia sebanyak 10 juta jiwa yang 
memiliki penghasilan rata-rata setidaknya Rp 500.000 sampai dengan Rp 10.000.000. sehingga dari perkiraan tersebut setidaknya uang wakaf yang dapat terkumpul sebanyak paling tidak 3 triliun setiap tahunnya dengan perhitungan wakaf sebagai berikut (Nasution dan Hasanah 2006):

Tabel 1. Proyeksi Wakaf Tunai

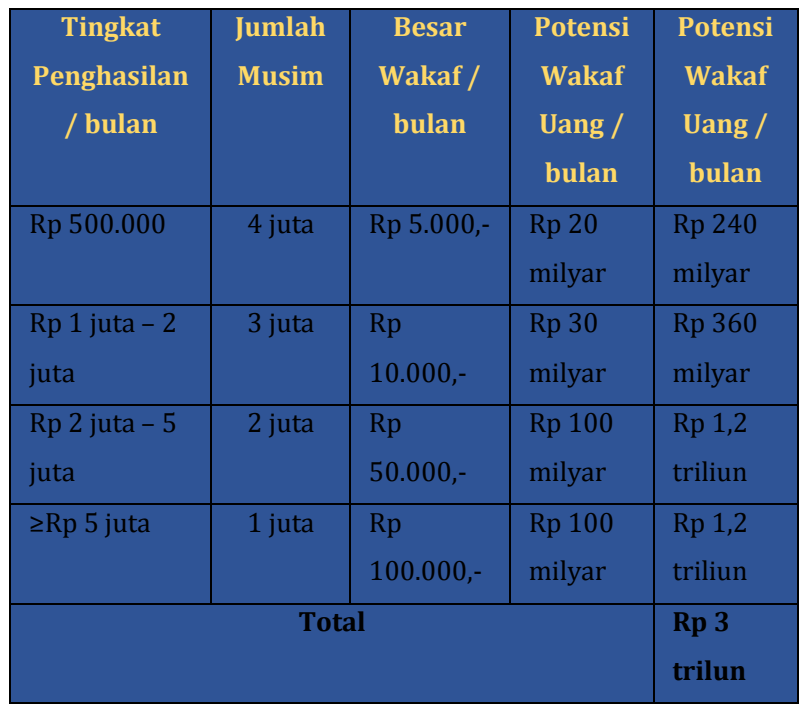

Dari seluruh total penduduk Indonesia yang berjumlah 230 juta jiwa, jika terdapat penduduk muslim yang mampu dan mau mewakafkan uangnya sebesar minimal Rp 1.000.000,-/ tahun dari 2 persennya saja atau sejumlah 4,6 juta jiwa, maka dana wakaf uang yang bisa terkumpul pertahun sebanyak Rp 4,6 triliun / tahun. Namun, Mustafa Edmin Nasution juga menyebutkan beberapa penyebab dari kecilnya potensi wakaf tunai yang terdapat di dalam perekonomian suatu negara antara lain (Nasution dan Hasanah 2006):

1. Masyarakat masih banyak yang tergiur dengan sistem ekonomi yang berbasis non syariah

2. Banyaknya masalah yang berbagai dengan pengelolaan lembaga wakaf.

3. Undang-undang wakaf yang komprehensif-integral masih belum ada.

4. Adanya berbagai masalah yang berkaitan dengan fikih wakaf.
Dari beberapa yang dikemukakan oleh Mustafa Edwin Nasutin ini sebenarnya potensi wakaf tunai dapat ditingkatkan lagi dengan tujuan kemaslahatan umat diberbagai bidang. Namun hal ini sulit dilakukan karena membutuhkan ahli atau pakar wakaf yang serius untuk merancang dan berinovasi untuk perkembangan wakaf dimasa yang akan datang. (Nasution dan Hasanah 2006)

Banyak negara-negara muslim yang berhasil menunjukkan wakaf dapat menjadi solusi dan berkontribusi dalam mengurai masalah perekonomian di suatu negara. Sebagai contoh wakaf di Mesir dikelola dalam berbagai infrastruktur seperti dalam bidang properti, bidang reklamasi tanah dan pertanian, bahkan di bidang ekonomi sendiri. Bahkan di Amerika Serikat yang penduduknya mayoritas non muslim juga memiliki aset wakaf yang produktif, yaitu sebuah proyek apartemen yang senilai US\$ 85 juta diatas tanah yang dimiliki oleh The Islamic Cultural Center of New York (ICCNY). Wakaf ini dikerjakan oleh lembaga yang profesional sehingga hasil yang diperoleh juga maksimal (Al Arif 2012). Sehingga dengan adanya wakaf ini dapat membentuk kemandirian umat dalam perekonomian. Dan juga wakaf dapat diperhitungkan sebagai instrument ekonomi islam dalam sebuah negara. Selain di negara luar, Indonesia sendiri juga memiliki wakaf yang nilainya cukup besar. Seperti penelitian yang telah dilakukan CSRC UIN Syarif Hidayatullah pada tahun 2003 terkait potensi wakaf yang ada di Indonesia. Hasil penelitian yang telah dilakukan bahwa ada sekitar 154 hektar wakaf oleh Kementrian Agama yang jika dirupiahkan senilai 590 triliun rupiah. Sehingga hal ini dapat membantu perekonomian yang ada di Indonesia (Al Arif 2012).

Dalam pembangunan infrastruktur di Indonesia, kerjasama yang dilakukan dengan pihak swasta sangat diperlukan 
oleh pemerintah. Kerjasama ini sering dikenal sebagai kerjasama pemerintah swasta atau konsesi (Syafiq 2017). Berikut ini bentuk kerjasama yang dapat dilakukan oleh lembaga wakaf.

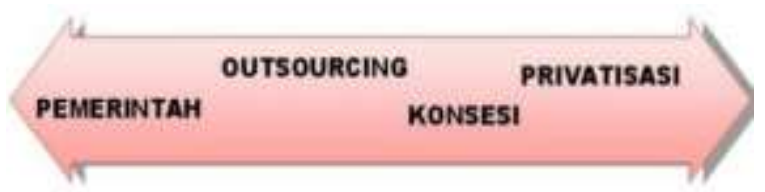

Gambar 1. Bentuk Kerjasama Wakaf

Pada bagian sebelah kiri pengelolaan dilakukan sepenuhnya oleh pemerintah sedangkan diujung sebelah kanan pengelolaan sepenuhnya dikuasai oleh pihak swasta. Pada outsourcing manajemen pengelolaan pegang oleh pihak luar dimana pihak tersebut berasal dari swasta, dan untuk konsesi pengelolaan dilakukan oleh pihak swasta sedangkan kepemilikan tetap dimiliki oleh pemerintah. Namun pengelolaan tersebut dapat kembali dimiliki oleh pemerintah ketika seluruh jangka waktu yang diperjanjikan selesai. (Syafiq 2017)

Wakaf tunai dapat menjadi solusi alternatif dalam pembiayaan infrastruktur di Indonesia. Dengan menggunakan wakaf tunai pembangunan inti tidak perlu memikirkan bagi hasil karena wakaf bukan termasuk pinjaman. Di Indonesia sendiri masalah wakaf masih sering menjadi perdebatan pada segi hukum fikih. Padahal seharusnya dengan wakaf dapat menjadi sumber dana maupun sebagai aset ekonomi yang dapat dikelola secara produktif dan juga dapat memberikan hasil kepada masyarakat. Untuk pengumpulan dana wakaf sendiri dapat dilakukan dengan memberikan kepada Badan Wakaf Indonesia yang termasuk lembaga yang independen. Ketika dana yang sudah masuk kepada BWI setelah periode tertentu dapat diserahkan kepada kementerian keuangan yang dimaksudkan ke kas negara. Kemudian dalam perannya Kementerian Keuangan dapat menggunakan uang tersebut untuk pembangunan infrastruktur. Dan oleh karena dana ini milik masyarakat muslim, maka dalam pengelolaannya harus menerapkan asas kehati-hatian, perlu adanya kajian dan juga penelitian atas nilai infrastruktur dari sisi kemanfaatannya bagi kemaslahatan umat dan peningkatan ekonomi umat. Dan juga diperhatikan juga sisi resiko hilangnya dana wakaf (Syafiq 2017).

Peranan Wakaf Tunai dalam Infrastruktur dan Meminimalisasi Kemiskinan

Di Indonesia kegiatan wakaf dikenal seiring dengan perkembangan dakwah Islam di Nusantara. Disamping melakukan dakwah Islam, para ulama juga sekaligus memperkenalkan ajaran wakaf. Hal ini terbukti dari banyaknya masjid-masjid yang bersejarah yang terus di bangun di atas tanah wakaf. Ajaran wakaf ini terus berkembang di bumi nusantara, baik pada masa dakwah pra kolonial, masa kolonial, maupun pasca kolonial pada masa Indonesia merdeka. Namun perkembangan wakaf dikemudian hari tak mengalami perubahan yang berarti. Kegiatan wakaf dilakukan terbatas untuk kegiatan keagamaan, seperti pembangunan masjid, musholla, langgar, madrasah, perkuburan, sehingga kegiatan wakaf di Indonesia kurang bermanfaat secara ekonomis bagi rakyat banyak.

Stagnasi perkembangan wakaf di Indonesia mulai mengalami dinamisasi ketika pada tahun 2001, beberapa praktisi ekonomi Islam mulai mengusung paradigma baru ke tengah masyarakat mengenai konsep baru pengelolaan wakaf tunai untuk peningkatan kesejahteraan umat. Konsep tersebut ternyata menarik dan mampu memberikan energi untuk menggerakkan

kemandegan perkembangan wakaf. Kemudian pada tahun 2002, Majelis Ulama Indonesia (MUI) menyambut konsep tersebut dengan mengeluarkan fatwa yang 
membolehkan wakaf uang (waqf alnuqud). Pada masa reformasi, pengelolaan wakaf semakin berkembang dengan terbitnya undang-undang yang khusus mengatur wakaf. Pada masa ini, landasan hukum pengelolaan wakaf menjadi lebih tinggi karena sudah dalam bentuk undang-undang. Peraturan perwakafan tersebut yaitu UndangUndang Nomor 41 Tahun 2004 Tentang Wakaf dan Peraturan Pemerintah Nomor 42 Tahun 2006 Tentang Pelaksanaan Undang-Undang Nomor 41 Tahun 2004 Tentang Wakaf. Hadirnya UndangUndang No. 41 Tahun 2004 tentang wakaf memberikan pijakan hukum yang pasti, kepercayaan publik, serta perlindungan terhadap aset wakaf. Pengesahan undangundang ini merupakan langkah strategis untuk meningkatkan kesejahteraan umum, meningkatkan peran wakaf, tidak hanya sebagai pranata keagamaan saja, tetapi juga memiliki kekuatan ekonomi yang potensial untuk memajukan kesejahteraan umum. Di samping itu, dengan disahkannya undang-undang ini, objek wakaf lebih luas cakupannya tidak hanya sebatas benda tidak bergerak saja, pemanfaatan wakaf untuk keperluan lain masih terkendali dengan terbatasnya pemahaman hukum pengelola wakaf. Sedangkan dimasa sekarang terjadi perluasan pengelolaan dan pengembangan harta wakaf kearah peningkatan kesejahteraan sosial ekonomi masyarakat berdasarkan UU No. 41 Tahun 2004 tentang wakaf (Sula 2009).

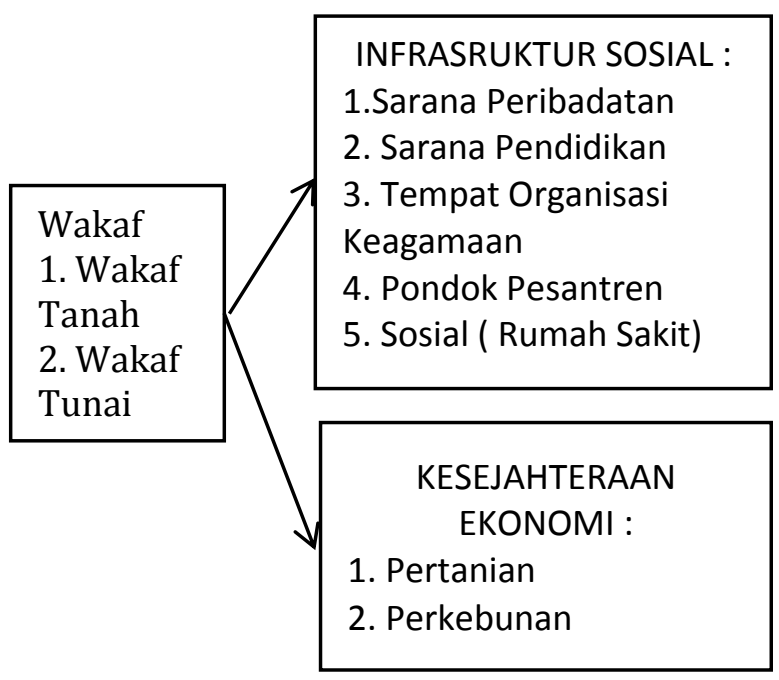

Gambar 2. Pengelolaan Wakaf

Gambar diatas menunjukkan bahwa sudah mulai berkembang proses pengelolaan wakaf. Wakaf yang dikembangkan pada sekarang ini tidak hanya bentuk tanah, tetapi juga dalam bentuk tunai. Sehingga harta wakaf dapat dikembangkan lebih maksimal yaitu tidak hanya pengembangan dalam bentuk infrasruktur sosial tetapi juga dapat dikembangkan dalam bentuk kesejahteraan ekonomi. Dengan manfaat harta wakaf dalam kesejahteraan ekonomi membuat harta wakaf dapat digunakan dalam bentuk produktif sehingga dapat menghasilkan manfaat bagi masyarakat. (Hazami 2016)

Sosialisasi pengenalan bentuk wakaf lain, berupa wakaf tunai, menjadi peristiwa cukup penting. Selain itu juga ada konsep wakaf produktif, konsep ini sangat penting untuk dikembangkan di Indonesia yang kondisi perekonomiannya tidak stabil. Wakaf tunai mempunyai peluang bagi terciptanya investasi di bidang keagamaan, pendidikan, dan pelayanan sosial. Di negara-negara muslim yang pengelolaan wakafnya lebih maju seperti, Mesir, Yordania, Saudi Arabia, Turki dan Bangladesh, wakaf tidak hanya dimanfaatkan dalam bentuk konsumtif tetapi juga dimanfaatkan dalam bentuk produktif. Selain sarana 
dan prasarana ibadah dan pendidikan wakaf juga dikembangkan dalam bentuk tanah pertanian, perkebunan, uang, saham, real estate dan lain-lain, sehingga hasilnya benar-benar mampu mewujudkan kesejahteraan umat. (Darwanto 2012)

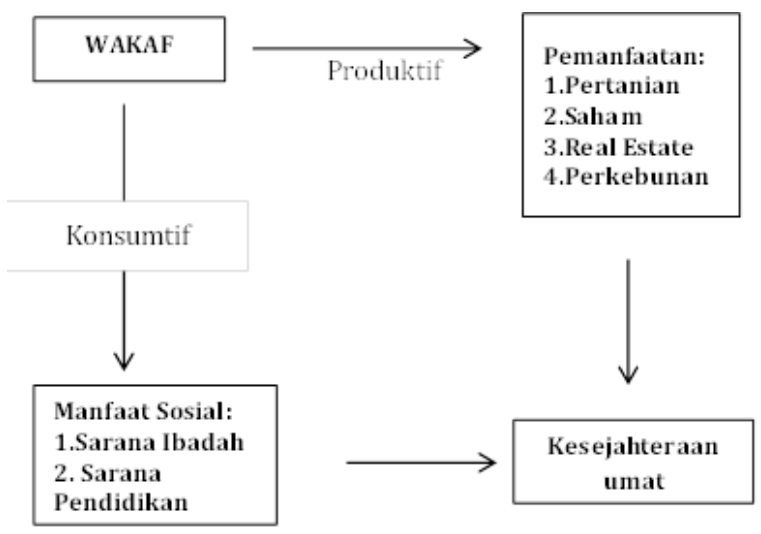

Gambar 3. Tujuan Pengelolaan Wakaf

Gambar diatas menunjukkan bahwa tujuan akhir dari pengelolaan dan pengembangan harta wakaf adalah untuk menciptakan kesejahteraan umat. Negara-negara muslim tersebut telah menerapkan tujuan kesejahteraan umat sebagai tujuan dalam pengelolaan wakaf. Sekarang ini, perwakafan Indonesia membutuhkan sebuah managemen yang modern untuk mengelola wakaf menjadi lebih produktif. Managemen yang lebih profesional dan modern diharapkan mampu menjadikan wakaf sebagai sarana untuk meningkatkan kesejahteraan ekonomi dan sosial umat di Indonesia.

Dalam pasal 34 amandemen UUD 1945 dikatakan bahwa negara mengembangkan sistem jaminan sosial bagi seluruh rakyat dan memberdayakan masyarakat yang lemah dan tidak mampu sesuai dengan martabat kemanusiaan. Berdasarkan amandemen UUD 1945 tersebut secara eksplisist bahwa negara harus mampu memberdayakan masyarakat. Terminologi pemberdayaan adalah membantu masyarakat agar mereka mampu menjadi mandiri dalam mensejahterahkan dirinya sendiri. Wakaf uang sebagai suatu gerakan baru dalam dunia perwakafan terutama di Indonesia mempu mengambil peranan yang signifikan dalam merancang programprogram pemberdayaan masyarakat.

Tugas memberdayakan masyarakat bukanlah tugas pemerintah semata, tetapi tanggung jawab setiap elemen masyarakat yang karenanya harus ikut serta dalam memberdayakan masyarakat. Progam pemberdayaan masyarakat dapat dilakukan dengan sistem perwakafan, hal ini sesuai dengan UU No. 41 Tahun 2004 tentang wakaf yang telah mengamanatkan Badan Wakaf Indonesia agar mengelola harta benda wakaf yang berskala nasional dan Internasional. Sifat utama perwakafan mengharuskan kekal dan abadi pokok hartanya, lalu dikelola dan hasilnya disalurkan sesuai dengan peruntukannya sangat sesuai dan selaras dengan progam sistem jaminan sosial atau asuransi. Dalam perwakafan, pihak wakif dapat menentukan peruntukan hasil pengelola harta wakaf.

Para pengelola lembaga wakaf di Indonesia harus peduli dalam mewujudkan masyarakat yang adil dan sejahtera. Lembaga wakaf terutama yang memiliki basis organisasi massa ataupun badan hukum, dapat menjadi salah satu sub-sistem alternatif di masyarakat yang saling bahu-membahu dengan sub-sistem masyarakat lainnya dalam menyelesaikan persoalan bangsa. Wakaf sebagai salah satu pranata keagamaan dalam Islam yang memiliki keterkaitan langsung secara fungsional dengan upaya pemecahan masalah-masalah sosial dan kemanusiaan seperti pengentasan kemiskinan, peningkatan sumber daya manusia dan pemberdayaan masyarakat.

Beberapa negara yang menganut negara kesejahteraan (welfare state) selama ini telah memberikan jaminan sosial dalam bentuk bantuan asuransi sosial kepada penduduk negaranya. Dengan adanya jaminan sosial dapat menunjang pembangunan nasional yang 
berkesinambungan. Apabila negara masih belum mampu membiayai suatu jaminan sosial kepada masyarakatnya, maka harus didukung dengan sub-sistem lain, hal inilah yang menempatkan wakaf sebagai salah satu sub-sistem pendukung negara untuk memberikan jaminan sosial. Hasil pengelolaan dana wakaf dapat diperuntukkan bagi pemberdayaan masyarakat, seperti pemberdayaan pendidikan, kesehatan, sosial ataupun ekonomi. Bentuk pemberdayaan pendidikan misalnya dengan mendirikan sekolah gratis dengan kualitas baik atau bantuan bagi kesejahteraan guru. Sedangkan pemberdayaan masyarakat dapat berupa pemeriksaan kesehatan dan pengobatan gratis bagi masyarakat kurang mampu, bantuan gizi ibu hamil, serta persalinan gratis. Pemberdayaan sosial dapat berupa pelatihan kerja dan kewirausahaan. Pemberdayaan ekonomi berupa bantuan dana bergulir.

Ada inisiatif dari pemerintah Indonesia untuk mengembangkan wakaf uang dalam rangka program menuntaskan kemiskinan. Potensi wakaf uang di Indonesia sangat menjanjikan, wakaf uang merupakan salah satu instrumen alternatif untuk mengurangi, masalah kemiskinan di dunia khususnya di negara-negara Islam.

Didalam sejarah Islam wakaf uang telah diamalkan sejak abad kedua hijrah. Diriwayatkan oleh imam Bukhari bahwa Imam Al Zuhri (wafat $124 \quad \mathrm{H}$ ) menganjurkan wakaf dinar atau dirham (uang) untuk pembangunan dakwah sosial dan pendidikan umat. Caranya adalah dengan menjadikan wakaf uang tersebut sebagai modal uasaha dan investasi yang abadi dan menyalurkan keuntungan yang dihasilkan sebagai dana wakaf (Beik, 2006).

Modal dari wakaf uang dapat dihandalkan apabila ia dapat membuat keuntungan dari usaha dan investasi secara perpetual (abadi). Ini sesuai dengan syarat-syarat harta wakaf. Harta yang diwakafkan harus bersifat perpetual dengan ini manfa'ah dari wakaf uang dapat diambil secara regular dan continual untuk diberikan kepada kegiatan amal. Seperti bantuan kepada masjid, rumah sakit, rumah yatim piatu, beasiswa, bantuan kepada fakir miskin, kemajuan dan peningkatan ekonomi umat, serta untuk kesejahteraan umum lainnya yang tidak bertentangan dengan syariah dan peraturan perundangundangan. Dengan demikian modal wakaf sebaiknya diinvestasikan oleh Nazhir (pengelola wakaf uang) ke dalam investasi syariah seperti Fixed Income Instruments (obligasi syariah), investasi mudharabah dan musyarakah yang bersifat low risk investment. Ada beberapa model pengelola wakaf uang yang sudah diimplementasikan di negara-negara Islam di dunia, salah satunya di Indonesia. Wakaf uang sudah diimplementasikan oleh dompet Dhuafa Batasa Syariah Mutual Fund (Reksadana) sejak Juli 2004 sebagai perusahaan reksadana syariah. Produk investasi utama mereka adalah fixed income instruments (Mohsin, 2008).

Reksadana ini dikelola oleh Batasa Capital Asset management. Modal wakaf uang yang digunakan ialah Waqf Mutual Fund Model. Bahwa waqif menginvestasikan uangnya untuk diinvestasikan sekaligus diwakafkan. Dalam kasus ini waqif akan menentukan sebanyak $70 \%$ dari untung modal investasinya akan dialokasikan ke rekening reksadana waqif, dan sebanyak $30 \%$ diberikan untuk dana wakaf dan didistribusikan untuk tujuan amal dan progam pemberantasan kemiskinan, Batasa dalam hal ini tidak hanya berperan sebagai Fund Manager tetapi juga sebagai Nazhir.

\section{KESIMPULAN DAN IMPLIKASI}

Wakaf adalah pemberian yang dilakukan dengan cara menahan (pemilikan) yang menjadikan manfaatnya 
tersebut dapat dimiliki oleh masyarakat umum. Disini yang dimaksud dengan kepemilikan adalah penahanan dari barang yang diwakafkan agar tidak di gadaikan, dijual, diwariskan, dihibahkan, didagangkan, maupun disewakan. Dan cara pemanfaatannya yaitu dengan cara menggunakan pemberian tersebut sesuai dengan yang dikehendaki oleh sang pemberi wakaf tetapi pemberi wakaf tersebut tanpa meminta imbalan. Secara umum tidak terdapat ayat Al-Qur'an yang menjelaskan konsep wakaf secara jelas, karena wakaf termasuk golongan infaq, maka dasar yang digunakan oleh para ulama dalam menjelaskan konsep wakaf berdasarkan pada ayat-ayat Al-Qur'an yang berkenaan dengan infaq. Potensi wakaf asumsi Cholil Nafis, apabila setiap bulan 20 juta umat islam mengumpulkan uang wakaf senilai Rp 100.000 maka uang wakaf yang terkumpul senilai $\mathrm{Rp} 24$ Triliun setiap tahunnya. Sedangkan jika terdapat 50 juta umat islam dengan mewakafkan uangnya sebesar Rp 100.000 maka uang wakaf yang terkumpul sebanyak Rp 60 Triliun. Dan jika hanya terdapat 1 juta orang yang mewakafkan uangnya maka akan terkumpul dana sebanyak Rp 100 miliar setiap bulannya (Rp 1,2 triliun pertahun). Sedangkan potensi wakaf menurut asumsi Mustafa Edwin Nasution. Dimana ia juga memperkirakan jumlah umat muslim yang ada di Indonesia sebanyak 10 juta jiwa yang memiliki penghasilan rata-rata setidaknya $\mathrm{Rp} 500.000$ samapi dengan $\mathrm{Rp} 10.000 .000$. sehingga dari perkiraan tersebut setidaknya uang wakaf yang dapat terkumpul sebanyak paling tidak 3 triliun setiap tahunnya.

\section{DAFTAR PUSTAKA}

Al Arif, M. Nur Rianto. "Wakaf Uang dan Pengaruhnya Terhadap Program Pengentasan Kemiskinan di
Indonesia." Indo-Islamika II, no. 1 (2012).

Ali, Muhammad Daud. Sistem Ekonomi Islam Zakat dan Wakaf. Jakarta: UI Press, 1988.

Al-Minawi. At-Taufiq ala Muhimmat Ta'arif. Cairo: Alamul Kutub, 1990.

Darwanto. "Wakaf Sebagai Alternatif Pendanaan Penguatan Ekonomi Masyarakat Indonesia." Jurnal Ilmu Manajemen Dan Akuntansi Terapan 3, no. 1 (2012): 7-8.

Fauzia, Amelia, and Ary Hermawan. Wacana dan Praktik Filantropi Islam. Jakarta: UI Press, 1988.

Hazami, Bashul. "Peran dan Aplikasi Wakaf dalam Mewujudkan Kesejahteraan Umat di Indonesia." Analisis XVI, no. 1 (2016): 178-179.

KHI. "Kompilasi Hukum Islam di Indonesia, Buku II, Bab I, Pasal 215, (1) dan (4)." n.d.

Nafis, Cholil. "Wakaf Uang Untuk Jaminan Sosial." Jurnal Al-Awqaf II, no. 2 (2009).

Nasution, Mustafa Edwin, and Uswatun Hasanah. Wakaf Tunai Inovasi Finansial Islam. Jakarta: PSTTI UI, 2006.

Qahaf, Mundzir. Sanadat Al-Ijarah, AlMa'had Al-Islamy Li Al-Buhuts Wa At-Tadrib. Cairo: Dar as-Salam, 1995.

Sula, M. Syakir. "Implementasi Wakaf dalam Instrumen Asuransi Syariah." Jurnal Al-Awqaf II, no. 2 (2009).

Syafiq, Ahmad. "Pemanfaatan Dana Wakaf Tunai Untuk Pembiayaan Pembangunan Infrastruktur." 
Jurnal Zakat dan Wakaf 4, no. 1 (2017). 